\title{
Kamu İlkokullarında Öğrenim Gören Dördüncü Sınıf Öğrencilerinin Çocuk Haklarına İlişkin Görüşleri*
}

\section{Opinions of Fourth Grade Public Primary School Students About}

Children's Rights

\section{Ülkü Çoban Sural, Naciye Aksoy}

\begin{tabular}{l}
\hline Yazar Bilgileri \\
\hline Ülkü Çoban Sural \\
Arş. Gör., Gazi Üniversitesi, \\
Eğitim Bilimleri Enstitüsü, Sınıf \\
Eğitimi, ulkusural@gazi.edu.tr
\end{tabular}

Naciye Aksoy

Prof. Dr., Gazi Üniversitesi,

Gazi Eğitim Fakültesi, Sınıf

Eğitimi, naciye@gazi.edu.tr

\section{ÖZ}

Bu çalışmanın amacı, kamu ilkokullarında öğrenim gören 4. sınıf öğrencilerinin çocuk olarak sahip oldukları haklara yönelik görüşlerini incelemektir. Nitel araştırma yöntemine göre gerçekleştirilen araştırmada, tipik durum örnekleme yoluyla çalı̧̧ma grubu oluşturulmuştur. Çalışma grubunda Ankara ilinin farklı ilçelerinde yer alan dört kamu ilkokulunun 4. sınıfında öğrenim gören 413 öğrenci yer almaktadır. Öğrencilerin görüşlerini alabilmek için açık uçlu yapılandırılmamış sorulardan oluşan ve araştırmacılar tarafından geliştirilen "Öğrencilerin Çocuk Haklarına İlişkin Görüşleri" anketi kullanılmıştır. Elde edilen verilerin analizinde betimsel analiz ve içerik analizi teknikleri bir arada kullanılmıştır. Çalışmanın sonucunda 4. sınıf öğrencilerinin çoğunluğunun "hak" kavramına yönelik bilgilerinin sınırlı olduğu görülmüştür. Öğrenciler, sahip olduklarını düşündükleri haklar arasında öncelikle ekonomik, sosyal ve kültürel haklara yer vermiştir. Haklarının ihlal edilmesi durumunda öğrencilerin çoğu tepkisiz kalacağını belirtmiştir. Öğrencilerin hakları konusunda okul yönetiminden beklentileri çoğunlukla "haklarının korunması ve kullanımına" yönelikken öğretmenlerden beklentileri ise çoğunlukla "eğitim süreci ve ortamına" yöneliktir.

\section{Makale Bilgileri \\ Anahtar Kelimeler \\ Çocuk Hakları \\ İlkokul \\ Dördüncü Sınıflar}

Keywords

Children Rights

Elementary School

Fourth Graders

Makale Geçmişi

Geliş: 15.01.2021

Düzeltme: 24.02.2021

Kabul: 26.02.2021

\begin{abstract}
The aim of this study is to examine the opinions of 4th-grade students in public primary schools about their rights as children. In the research, which was carried out according to the qualitative research method, the study group was formed through typical case sampling. The study group consists of 413 students from the 4th grade of four public primary schools in different districts of Ankara. The "Opinions of the Students on Children's Rights" questionnaire, which consists of open-ended unstructured questions and was developed by the researchers, was used to get the students' opinions. Descriptive and content analysis techniques were used together for data analysis. As a result of the study, it was seen that most of the 4th-grade students had limited knowledge about the concept of "right". Among the rights that students think they have, first of all, are economic, social and cultural rights. Most of the students stated that if their rights were violated, they would remain unresponsive. While the expectations of the students from the school management regarding their rights were mostly related to the "protection and use of their rights", their expectations from teachers were mostly about the "educational process and environment".
\end{abstract}

${ }^{*} \mathrm{Bu}$ çalışma birinci yazarın ikinci yazar danışmanlığında yürütmüş olduğu yüksek lisans tezinden üretilmiş olup, 3. Uluslararası Eğitim, Uzaktan Eğitim ve Eğitim Teknolojileri Kongresi'nde sözlü bildiri olarak sunulmuştur. 


\section{Giriş}

Bir toplumun mutluluğu ve refahı o toplumdaki çocukların mutluluğu ve refahı demektir (AyZöğ, 2008). Ülkeler gerek maddi gerekse manevi açllardan mutluluğa ulaşmak arzusunda iseler imkânlarının büyük bir kısmını, toplumda yer alan çocukların sağlıklı büyümesine ve yetenekleri doğrultusunda geliştirilebilmelerine harcamak zorundadırlar (Akyüz, 2000, s. 1). Bir toplumda çocuklar istismara uğruyor, kötü muamele görüp ihmal ediliyorsa o toplumun geri kalmış bir kültüre sahip olduğu söylenebilir. Çocuklara kıymet veren, koruyan, sağlıklı büyüme ve gelişebilme olanakları sunan toplumlar ise ileri ve ilerlemekte olan bir kültürle karakterize edilmektedir (Ay-Zöğ, 2008).

Çocuk, eski çağlardan beri hukukun ilgi alanında yer alan bir varlıktır (İnan, 1968, s. 3). Ancak çocukların haklarının hukuk kuralları çerçevesinde ele alınması Yeni Çağda başlamıştır (Akyüz, 2016). Çocukların her türlü istismar ve ihmalden korunması yönünde örgütlerin kurulması düşüncesi, merkezlerin açılması ve özellikle Birinci Dünya Savaşı'ndan sonra yayınlanan bildirgelerden sonra (Akyüz, 2000) çocuğun kendine özgü haklara sahip olduğu kabul edilmiş ve bu haklara sistemli bir şekilde hem ulusal hem de uluslararası metinlerde yer verilmeye başlanmıştır. Birleşmiş Milletler (BM), on sekiz yaşın altında olan çocukların da insan hakları ve anayasal temel haklardan faydalanması gerektiğini ifade etmiş ve Çocuk Hakları Sözleşmesi'ni (ÇHS) 20 Kasım 1989'da kabul etmiştir. Yürürlüğe girmesi 2 Eylül 1990 tarihinde gerçekleşen Sözleşme, tarihte en yaygın şekilde onaylanan insan hakları belgesi olma özelliğini taşımaktadır (Özdemir-Uluç, 2008). Türkiye Cumhuriyeti ise ÇHS'yi 1994 yılında onaylamıştır (Fazlıŏlu, 2007).

Sözleşme'yi onaylayan devletler, dünyadaki bütün çocukların yaşama, gelişme, korunma ve katılım haklarının tanınması ve korunması konusunda çok değerli ve önemli bir adım atmışlardır. Aynı zamanda Birleşmiş Milletler, ÇHS'yi imzalayan taraf devletlere, Sözleşme'nin 42'nci maddesi ile ÇHS'de yer alan maddeleri çocuk ve yetişkinlere yaygın şekilde tanıtarak öğretme sorumluluğu yüklemiştir. Ancak Ay-Zöğ’e (2008) göre Sözleşme'nin ardından yapılan birçok araştırmada çocukların, kendileri adına iyi olan şeylerin neler olduğu bilgisine sahip olmadıkları ortaya konulmuştur. Ayrıca çocuklara karşı sergilenen davranışların çoğu genel olarak yetişkinlerin gözlemlerine dayanmaktadır. Yetişkin gözlemleri doğrultusunda bilgi toplama yöntemi önemlidir fakat yeterli değildir.

Karaman-Kepenekçi (2000, s. 16), insanların haklarını bilmelerinin onların hakları ve sorumlulukları hakkında bilinçlenmelerini sağlayacağını belirtmektedir. Bu bilinçlenmenin çocuklukta başlaması yetişkinlik dönemi açısından olumlu sonuçlar doğuracaktır. Çocukluk döneminde insan hak ve sorumluluklarına yönelik en sağlıklı bilinçlenme ise eğitim kurumlarında sağlanabilir. Bu nedenle öğrencilerin sahip oldukları hakları erken yaşlarda öğrenmeleri hem kendileri hem de bütün toplum için demokratik süreçlerinin işletilmesi ve demokratik toplum düzeninin oluşturulması açısından 
önemli faydalar sağlayacaktır. Haklarını bilmek kişinin kendisine saygısının ve güveninin gelişmesinde önemli bir unsurdur ve bu durum çocuklar için de geçerlidir. Onların özgüven sahibi bireyler olarak yetişmesinde haklarını bilmeleri önemli bir rol oynamaktadır. Kişilerin özgüvene sahip olmaları, kendilerine ve diğerlerine değer vermeleri, onları medeni haklarını kullanma konusunda ve sosyal yaşamda rol almada daha faal bireyler hâline dönüştürmektedir.

Çocuk başta aile ve okul olmak üzere içinde bulunduğu çevrede kendine ve başkalarına karşı saygı duymayı deneyimler. Başkalarına saygı duyma çocukların sahip oldukları hakları bilmelerinin neticesinde elde edebilecekleri bir kazanımdır. Bu kazanım beraberinde empati becerisinin gelişmesi ve bencilliğin yok edilmesine de imkân sunar. Çünkü çocuklar haklarını öğrendiklerinde bu hakların sadece kendileri için değil diğer tüm çocuklar ve insanlar için de geçerli olduğunu öğrenir. Bunların yanı sıra haklarını bilmek kalıp yargılara yönelimi de azaltarak çocukların eleştirel düşünebilmelerinin yolunu açar. Çocuklarının toplum içerisinde haklarının bilincinde olmaları, haklarını en iyi biçimde kullanabilmeleri ve haklarından yüksek düzeyde yarar sağlamaları onların ahlaki anlamda gelişebilmelerine de katkı sağlar (Karaman-Kepenekçi, 2000, s. 17-21).

İlköğretim dönemi hak ve sorumluluklarla ilgili bilgi, beceri ve anlayış kazandıracak ilk basamaktır. Çünkü çocuklar kişisel değer ve tutumlar ile temel vatandaşlık yeterliklerini ilköğretim döneminde kazanırlar. Bu açıdan Birleşmiş Milletler de 1991 yılında ÇHS'ye taraf olan ülkelere çocuk hakları eğitimi ile ilgili bazı önerilerde bulunmuştur. Bu önerilerden biri, bu işi eğitim aracılığıyla yapmak ve eğitim programlarının içeriğine çocuk haklarını da eklemek olmuştur. Bu öneriler üzerine $\mathrm{ABD}$, İsviçre, İngiltere, Kanada gibi pek çok ülkede çocuk hakları, eğitim programlarına dâhil edilmiştir (Ersoy, 2011).

Çocuk Hakları Eğitimi (ÇHE) savunucuları, bu eğitimin verilmesinde üç farklı perspektif benimsemekte ve bu görüşler mevcut eğitim biçimini etkilemektedir. Bu perspektiflerden ilki, çocuk hakları eğitiminin teknik olarak uygulanması gerektiğinin savunulduğu hukuki perspektif; ikincisi çocuklarla ilgili yasal metinlerinin yorumlanması ve detaylandırılmasına odaklanan reformist/yoruma dayalı perspektif; üçüncüsü ise çocuk hakları eğitimini daha geniş bir politik mücadelenin parçası olarak gören radikal perspektiftir. Hukuki perspektif, çocuk hakları eğitimini siyasi açıdan tartışmaya kapalı, nispeten tarafsız bir fikir kümesi olarak ele almaktadır. Bu görüşe göre uluslararası bildirgeler, sözleşmeler, kararlar ve diğer çeşitli araçlar ÇHE'yi tanımlayan ve üzerinde anlaşmaya varılan bir çerçeve sunmaktadır. Reformist/yoruma dayalı perspektif, Sözleşme'yi ayrıntılı bir rehberlikle ayrıntılandıran Çocuk Haklarına Dair Komitenin yayınladığı Genel Yorumlar ile BM içinde temsil edilmektedir. Bu perspektif, hukuki perspektife nazaran ÇHE'nin politik görüşünü daha açık bir şekilde geliştirmeye doğru ilerlemektedir. Ayrıca çocuk hakları eğitiminin müfredat, eğitim süreçleri ve kurumlar için etkileri olduğunu ve çocuk katılımı ile akran eğitimi gerektirdiğini belirtmektedir. 
Üçüncü ve son perspektifte ise ÇHE ile ilgili olarak çeşitli modeller geliştirmeyi hedeflemektedir (Jerome, 2016).

Ülkemizde çocuk hakları, 1990'ların sonu itibariyle eğitim programlarına yansıtılmaya çalışılmış ve ders içeriklerinde bazı düzenlemelere gidilmiştir. Çocuk haklarının ilkokul 1, 2, 3 ve 4'üncü sınıflardaki derslerin içeriklerinde yer alma durumlarını inceleyen Özdemir-Uluç (2008) çalışmasında çocuk haklarının eğitim programlarındaki yeri ve önemine ilişkin şu değerlendirmeleri yapmaktadır. Türkiye'de hayat bilgisi, sosyal bilgiler ve Türkçe derslerinin öğretim programlarının içeriğinde çocuk haklarına ilişkin bazı konular bulunmaktadır. Ancak programlarda yer alan çocuk haklarının daha çok gelişme ve katılım haklarından oluştuğu, yaşama ve korunma haklarına ise çok az yer verildiği görülmektedir. Programlarda çocuk haklarına bilinçli bir şekilde yer verilen bölümlerde dahi kazanımların içselleştirilmediği konuyla ilgili etkinliklerden anlaşılmaktadır. Bu durum programların çocuk hakları konusunda oldukça yüzeysel bir farkındalık ile hazırlandığının göstergesidir. Türkçe dersi toplam ders saati sayısının fazlalığı ve tüm sınıflarda okutuluyor olması açısından çocuk haklarının eğitimi konusunda yüksek bir potansiyele sahip olmasına rağmen yeterince değerlendirilememiştir. Çocuk haklarıyla ilgili kazanımların derslere dağılımı da bilimsel tutarlılık çerçevesinde yapılmamıştır. Bütün programlarda çocukların, gelecekteki yurttaş ve toplumdaki yetişkin bir üye olacakları zaman sahip olacakları roller ve sorumluluklar için diğer bir deyişle gelecek için hazırlanmakta oldukları gözlemlenmektedir. Bu nedenle çocuk hakları geri planda kalmaktadır. Ayrıca çocukların haklarını anlama ile ilgili olarak yeterli olmayan bir muhakeme gücüne sahip oldukları düşüncesinin de etkili olduğu dikkat çekmektedir. Çocuğun yaşı ilerledikçe anlama kapasitesinde de artış olacağı dikkate alınmadığından üst sınıflarda çocuk haklarına daha fazla yer verilmesi gerekirken böyle bir yol izlenmemiştir. Programlarda önerilmekte olan etkinlikler yeterli derecede yapılandırılmadığından programın amaçlarına ulaşabilmesi öğretmenlerin yetkinliklerine ve yeterliklerine kalmaktadır.

Türkiye'de hayat bilgisi, sosyal bilgiler ve Türkçe derslerinin yanı sıra çocuk hakları ile yakından ilişkili olan demokrasi ve insan hakları eğitiminin sistematik bir biçimde verilebilmesi için bazı adımlar atılmış ve ilkokul 4. sınıf ders programına 2015-2016 öğretim yılında "İnsan Hakları, Yurttaşlık ve Demokrasi" dersi eklenmiştir. Ancak Izgar'a (2017) göre bu dersin kitabındaki etkinliklerde çeşitlendirmeye gidilmesi gerekmekte, yalnızca metin ve sorulardan oluşan bir kitabın istenen seviyede bir insan hakları eğitimi sağlaması mümkün görülmemektedir.

Çocuklara hakları ve sorumluluklarını öğretecek yeni bir programın geliştirilmesinde veya mevcut programın aksayan yönlerinin tespit edilmesinde programın hedef kitlesinin neyi ne kadar bildiğinin tespit edilmesi önemlidir. Bu tespitin yapılabilmesi için de çocuklar tarafından haklarının ne kadar bilindiği sorusu akıllara gelmektedir. Bu açıdan çalışmada "Kamu ilkokullarında öğrenim gören 
4. sınıf öğrencilerinin çocuk olarak sahip oldukları haklarına yönelik görüşleri nelerdir?" sorusuna ve bu soruyu ayrıntılandıran " 4 . sınıf öğrencilerine göre "hak" kavramı ne anlama gelmektedir?, Öğrenciler, sahip oldukları haklarından hangilerini bilmektedir?, Haklarının ihlal edilmesi durumunda nasıl tepki vermektedir?, Çocuk haklarını bilme, kullanma ve koruma konusunda okul yönetiminden ve öğretmenlerden neler beklemektedir?" alt sorularına yanıt aranmıştır.

\section{Yöntem}

$\mathrm{Bu}$ araştırma, nitel araştırma yaklaşımına göre gerçekleştirilmiştir. Nitel yaklaşımda olaylar, olgular, algılar, duygular ve görüşler gözlem, görüşme ve doküman incelemesi gibi çeşitli veri toplama yollarıyla doğal ortamda gerçekçi ve bütüncül bir biçimde incelenerek açılanmaya çalışılır (Yıldırım ve Şimşek, 2016, s. 39). Bu araştırmada ilkokul 4. sınıf öğrencilerinin çocuk haklarının farklı boyutlarına yönelik görüşlerinin nasıl olduğu sorusuna yanıt aranmıştır. Öğrencilerin görüşleri sınırlandırılmış sorulardan oluşan ölçme araçları yerine detaylı ve özgün veriler sunan açık uçlu soruların cevaplanması yoluyla ortaya konulmuştur. Araştırmaya gönüllü olarak katılan öğrencilerin çocuk haklarına yönelik görüş, düşünce ve bilgilerine hiçbir şekilde müdahale edilmemiş, görüş ve düşünceler var olduğu şekliyle betimlenmiştir.

\section{Çalışma Grubu}

Araştırmanın çalışma grubunu, Ankara ilinin Etimesgut, Çankaya, Pursaklar ve Altındağ ilçelerinde yer alan dört kamu ilkokulunun 4. sınıfında öğrenim gören ve veri toplama aracını gönüllü olarak doldurmayı kabul eden 413 öğrenci oluşturmaktadır. Çalışma grubu amaçlı örnekleme yöntemlerinden tipik durum örneklemesi yoluyla oluşturulmuştur.

Tipik durum örneklemesinde birkaç durum arasından en tipik bir ya da birkaçı belirlenerek çalışılabilir. Burada amaç sonuçları evrene genellemekten ziyade, ortalama durumların çalışılması yoluyla belli bir alanla ilgili bilgi sahibi olabilmektir. Nitel araştırmaların örnek ve bakış açısı oluşturma yöntemiyle tecrübe edindirme fonksiyonu, bu tip örnekleme yönteminin kullanıldığı çalışmalarda açık ve net bir şekilde ortaya çıkmaktadır (Yıldırım ve Şimşek, 2016, s.110). Bu çalışmada tipik durum örneklemesi yoluyla seçilen gruptaki öğrenciler sosyo-ekonomik düzey bakımından ne çok üstte ne de çok altta olacak şekilde, orta sosyo-ekonomik düzeyden seçilmiştir. Verilerin toplanacağı okulların sosyo-ekonomik düzeylerinin tespit edilmesinde okul yöneticilerinin görüşleri temel alınmıştır.

Akademik ve sosyal açıdan olgunluk düzeylerinin alt sınıflardaki öğrencilere göre daha gelişmiş̧ olması; kendilerini yazılı ve sözlü olarak daha rahat bir şekilde ifade edebilecek olmaları ve ilkokul 1, 2 ve 3. sınıflarda özellikle hayat bilgisi dersinde ve 4. sınıfta sosyal bilgiler ile insan hakları, yurttaşlık ve demokrasi derslerinde yer alan çocuk hakları ile ilgili konuları öğrenmiş olmaları nedeniyle çalışma grubunda 4. sınıf öğrencilerinin yer alması özellikle tercih edilmiştir. 
Çalışma grubunun ayrıntılı bir biçimde tanımlanabilmesi için araştırmaya katılan öğrencilere okul dışı yaşantılarına yönelik de bazı kişisel bilgileri sorulmuş ve sorulara verilen yanıtlar doğrultusunda elde edilen bilgiler Tablo 1'de sunulmuştur.

Tablo 1. Öğrencilerin Kişisel Bilgilerine Göre Dağılımı

\begin{tabular}{|c|c|c|c|}
\hline Değişkenler & Kategoriler & $N$ & $\%$ \\
\hline \multirow{3}{*}{ Cinsiyet } & $\mathrm{K}_{1 \mathrm{Z}}$ & 205 & 49,64 \\
\hline & Erkek & 208 & 50,36 \\
\hline & Toplam & 413 & 100 \\
\hline \multirow{5}{*}{ Anne eğitim durumu } & Okuryazar değil & 9 & 2,18 \\
\hline & İlköğretim & 231 & 55,93 \\
\hline & Ortaöğretim & 99 & 23,97 \\
\hline & Yükseköğretim & 74 & 17,92 \\
\hline & Toplam & 413 & 100 \\
\hline \multirow{3}{*}{$\begin{array}{l}\text { Anne çalışma } \\
\text { durumu }\end{array}$} & Çalışıyor & 138 & 33,41 \\
\hline & Çalışmıyor & 275 & 66,59 \\
\hline & Toplam & 413 & 100 \\
\hline \multirow{5}{*}{ Baba Eğitim Durumu } & Okuryazar değil & 7 & 1,69 \\
\hline & İlköğretim & 185 & 44,79 \\
\hline & Ortaöğretim & 123 & 29,78 \\
\hline & Yükseköğretim & 98 & 23,73 \\
\hline & Toplam & 413 & 100 \\
\hline \multirow{3}{*}{$\begin{array}{l}\text { Baba Çalışma } \\
\text { Durumu }\end{array}$} & Çalışıyor & 402 & 97,34 \\
\hline & Çalışmıyor & 11 & 2,66 \\
\hline & Toplam & 413 & 100 \\
\hline \multirow{3}{*}{$\begin{array}{l}\text { Okul dışında } \\
\text { katıldığı sosyo- } \\
\text { kültürel faaliyetler } \\
\text { (spor, sanat, eğitim) }\end{array}$} & Evet & 150 & 36,32 \\
\hline & Hayır & 263 & 63,68 \\
\hline & Toplam & 413 & 100 \\
\hline
\end{tabular}

Tablo 1'de de görüldüğü gibi çalışmaya katılan toplam 413 öğrencinin 205'i $(\% 49,64)$ kız, 208'i $(\% 50,36)$ erkektir. Oranlar dikkate alındığında kız ve erkek öğrencilerin eşit düzeyde katılımı söz konusudur. Öğrencilerin annelerinin eğitim durumları incelendiğinde; dokuz $(\% 2,18)$ öğrencinin annesinin okuryazar olmadığı, 231'inin (\%55,93) ilköğretim mezunu, 99'unun $(\% 23,97)$ ortaöğretim mezunu ve 74 'ünün $(\% 17,92)$ ise yükseköğretim mezunu olduğu görülmektedir. Öğrencilerin $138^{\prime}$ inin $(\% 33,41)$ annesi çalışmakta iken 275 'inin $(\% 66,59)$ annesi ise herhangi bir işte çalışmamaktadır. Babalarının eğitim durumları incelendiğinde ise yedi $(\% 1,69)$ öğrencinin babasının okuryazar olmadığı, 185'inin (\%44,79) ilköğretim mezunu, 123'ünün (\%29,73) ortaöğretim mezunu ve son olarak 98'inin (\%23,73) ise yükseköğretim mezunu olduğu görülmektedir. Öğrencilerin babalarının 402'si $(\% 97,34)$ çalışırken 11'i $(\% 2,66)$ çalışmamaktadır. $150(\% 36,32)$ öğrenci okul dışında spor, sanat, eğitim gibi sosyo-kültürel faaliyetlere katılmaktayken 263 ü $(\% 63,68)$ bu türden herhangi bir faaliyete katılmamaktadır. 


\section{Veri Toplama Araçları}

Öğrencilerin çocuk hakları ile ilgili görüşlerini doğallıkla ortaya koyabilmek için açık uçlu yapılandırılmamış sorulardan oluşan ve araştırmacılar tarafından geliştirilen “Öğrencilerin Çocuk Haklarına İlişkin Görüşleri Anketi” kullanılmıştır.

Açık uçlu sorular katılımcların veri toplama aracını detaylı ve özgün bir biçimde cevaplamaları istendiğinde kullanılır. Yapılandırılmamış sorular adıyla da bilinen açık uçlu soruların kullanıldığı çalışmalarda cevaplayıcı, sorulara serbest bir biçimde cevaplar verir. Bu nedenle açık uçlu sorular araştırmacının beklemediği cevapları da alabilmesini sağlar ve bu bakımdan avantajlıdır. Bu sayede konu ile ilgili çok daha geniş kapsamlı ve ayrıntılı bilgilere erişim sağlanır. Açık uçlu sorular; yorumlama, listeleme ve boşluk doldurma soruları biçiminde üç grupta sınıflanır (Büyüköztürk, KılıçÇakmak, Akgün, Karadeniz ve Demirel, 2009, s. 164). Bu araştırmada açık uçlu soruların bu üç türünün hepsi kullanılmıştır. Anket iki bölümden oluşmaktadır. Birinci bölümde öğrencilerin kişisel bilgilerine yönelik altı ve ikinci bölümde ise çocuk haklarına yönelik beş soru sorulmuştur. İkinci bölümde yer alan sorular aşağıdaki gibidir:

1. Sence "hak" nedir? "Hak" denince aklına ne geliyor?

2. Sence çocuk olarak sahip olduğun haklar nelerdir?

3. Hakların elinden alındığında neler yaparsın? Nasıl bir yol izlersin?

4. Çocuk olarak sahip olduğun haklar konusunda okul yönetimi ne yapmalı?

5. Çocuk olarak sahip olduğun haklar konusunda öğretmenler ne yapmalı?

\section{Verilerin Toplanması}

Araştırmanın verileri, yazışma yoluyla toplanmıştır. Yazışma, verilerin "açık uçlu / yapılandırılmamış" ya da "kapalı uçlu / yapılandırılmış" sorularla yazılı iletişim yoluyla toplanmasıdır (Illhan, 2015; Karasar, 2017, s. 175). Bu araştırmada veriler açık uçlu sorular ile toplanmıştır.

Veri toplama sürecinin öncesinde Gazi Üniversitesi Etik Komisyonundan ve Ankara İl Milli Eğitim Müdürlüğü'nden gerekli yasal izinler alınmıştır. Veri toplama aracı, okullar tek tek ziyaret edilerek çalışmaya katılma noktasında gönüllü olduğunu beyan eden öğrencilere dağıtılmış ve cevaplama işleminin ardından toplanmıştır. Veri toplama aracının nasıl doldurulacağına yönelik bir açıklama araca eklenmiş, gerektiği durumlarda sözel açıklamalarda da bulunulmuştur. Bu konuda özellikle kişisel bilgilerin ve görüşlerin gizliliğinin nasıl sağlanacağı ve istendiği takdirde araştırmaya katılmaktan çekilebileceklerine yönelik bilimsel etik ilkeler doğrultusunda açıklamalar yapılmıştır. 


\section{Verilerin Çözümlenmesi ve Yorumlanması}

Açık uçlu sorulardan elde edilen verilerin betimlenmesi zor ve karmaşık bir süreçtir. Bu tür verilerin analizinde kategorilerin oluşturulmasında çok özenli davranmak gerekir. Çalışmada verilerin analizinde betimsel ve içerik analizi kullanılmıştır. Betimsel analiz tekniğinde veriler önceden belirlenmiş olan temalara göre özetlenir ve yorumlanır. İçerik analizi tekniğinde ise birbirine benzeyen veriler, belirli kavramlar ve temalar çerçevesinde bir araya getirilir ve okuyucunun anlayabileceği bir biçimde organize edilerek yorumlanır (Yıldırım ve Şimşek, 2016, s. 224).

Bu çalışmada veri kaybına ya da yanlış veri düzenlemesine sebep olmamak için kategorilerin bir kısmı literatüre dayalı olarak oluşturulmuştur. Örneğin, çocukların "hak" kavramının ne olduğuna yönelik yanıtlarının kategorilendirilmesinde Melton'ın (1980) çalışmasında kullandığı kategorilerden (bkz. Tablo 2) faydalanılmıştır. Çocukların sahip olduklarını düşündükleri haklarının kategorilendirilmesinde ise Akyüz'ün (2016, s. 64-80) haklar sinıflamasindan (bkz. Tablo 4) yararlanılmıştır.

Çalışmada yer alan diğer sorulara verilen yanıtlar, içerik analizi yapılarak uzman görüşü çerçevesinde birbirine benzeyen belirli kodlar ve kodlardan ulaşılan kavramlar bir araya getirilerek kategorilendirilmiştir. Örneğin hakları elinden alındığında izleyecekleri yola ilişkin olarak öğrencilerin cevapları sınıflandırılmış ve "tepkisizlik" ile "savunma yolları" adlı iki tema oluşturulmuştur. "Savunma yolları" teması ise kendi içerisinde "bireysel mücadele" ve "ortak mücadele" olarak ikiye ayrılmıştır. Benzer şekilde öğrencilerin çocuk olarak sahip oldukları haklar konusunda okul yönetimi ve öğretmenlerden beklentilerine ilişkin olarak, öğrenci cevaplarının benzerliklerine göre kategorilendirilmesi sonucunda, "hakların korunması ve kullanımına ilişkin beklentiler", "eğitim süreci ve ortamına ilişkin beklentiler" ve "demokratik tutum ve davranışlara ilişkin beklentiler" olmak üzere üç tema oluşturulmuştur. Veriler bu çerçeveye göre işlenmiş, daha sonra bulgular tanımlanarak yorumlanmıştır.

Temel içerik analizinde verilerin analizi genellikle niceldir ve tanımlayıcı istatistiklerin kullanımına odaklanır. Araştırmacılar, incelenen verileri açıklamak için belirli içerik veya olayların sayılarını veya sıklığını kullanır (Drisco ve Maschi, 2016). Bu çalışmada da anlaşılırlığı kolaylaştırmak adına sorulara verilen cevaplar frekans ve yüzde olarak tablo hâline getirilmiş ve zaman zaman doğrudan alıntılara da yer verilmiştir. Doğrudan alıntılara yer verilirken çalı̧̧maya katılan öğrencilerin her birine "katılımcı" anlamına gelen " $K$ " harfi ile öğrencinin doldurduğu anket numarasından oluşan bir kod verilmiştir. Örneğin 5 numaralı anketi dolduran öğrencinin bir ifadesi alınacaksa çalışmada bu öğrenciye "K5" kodu ile yer verilmiştir.

Katılımcların görüşlerinin birden fazla kategori içerisinde kodlanmış olması nedeniyle görüş sayısı katılımcı sayısından fazla olduğu için frekansların toplamı, toplam kişi sayısı olan 413'ü ve 
yüzdelerin toplamı ise \%100'ü vermemektedir. Öğrencilerin tek bir cevap seçeneğini işaretlediği sorularda ise belirtilen değerler sağlanmakta ve frekansların toplamı 413'ü, yüzdelerin toplamı ise $\% 100$ 'ü vermektedir.

\section{Geçerlik ve Güvenirlik}

Genellikle nicel araştırmaların önemli değer ölçütleri biçiminde kabul edilen "geçerlik" ve "güvenirlik" kavramları nitel araştırmalarda doğası gereği değiştirilerek alternatif kavramlar ile ifade edilmektedir. Bu bağlamda nitel araştırmalarda, nicel araştırmalarda yer alan "iç geçerlik" yerine "inandırıcılık", "dış geçerlik" yerine "aktarılabilirlik", "iç güvenirlik" yerine "tutarlık" ve "dış güvenirlik" yerine ise "teyit edilebilirlik" kavramları kullanılmaktadır (Yıldırım ve Şimşek, 2016).

$\mathrm{Bu}$ araştırmada inandırıcılığın değerlendirilmesinde uzman incelemesi yöntemi kullanılmıştır. Bu kapsamda araştırma konusu ile ilgili genel bilgiye sahip ve nitel araştırma yöntemlerinde uzman olan üç kişiden, araştırmayı farklı boyutlarıyla incelemesi istenmiştir. Ek olarak veri toplama aracının oluşturulmasında da uzman görüşleri alınmış, uzmanlardan gelen geri bildirimlere dayalı olarak veri toplama aracı yeniden gözden geçirilmiştir. Ayrıca Silverman'ın (2018, s. 162) ifade ettiği şekliyle farklı kodlayıcıların içerik analizinde aynı sonuçlara ulaşmasını sağlayacak nitelikte açık ve net kategorilerin oluşturulmasını sağlayabilmek için de uzman görüşünden faydalanılmıştır. Böylece Guion'un (2002) belirttiği gibi tek bir veri kümesinin yorumlanması için birden fazla uzmanın perspektifi kullanılarak araştırmacı üçgenlemesi gerçekleştirilmiştir.

Araştırmada aktarılabilirliğin değerlendirilmesinde ise ayrıntılı betimleme yöntemi kullanılmıştır. Yıldırım ve Şimşek'e (2016, s. 270) göre nitel araştırmalarda sonuçların aktarılabilirliği, araştırmadan elde edilen verilerin yeterli bir şekilde betimlenmesiyle mümkün olur. Ayrıntılı betimlemede ham veri yorum katılmadan, orijinal hâli bozulmadan sunulur. $\mathrm{Bu}$ amacın gerçekleştirilebilmesi için doğrudan alıntılar yapılabilir. Bu sayede okuyucular da araştırmadan kendi sonuçlarını çıkarabilme olanağı sağlarlar. Bu araştırmada aktarılabilirliğin sağlanabilmesi için doğrudan alıntılara yer verilmiştir.

Araştırmada tutarlığın değerlendirilmesinde tutarlık incelemesinden faydalanılmıştır. Tutarlık incelemesinin amacı araştırmacının ortaya koyduğu araştırmaya yönelik etkinliklerde tutarlı davranıp davranmadığını belirlemektir (Yıldırım ve Şimşek, 2016). Bu nedenle araştırmadan elde edilen verilerin sonuçlarla ilişkilendirilmesinin yapılması gerekmektedir. $\mathrm{Bu}$ araştırmada da araştırmaya ait veriler araştırma bittikten sonra sonuçlarla tekrar karşılaştırılmış ve tutarlık sağlanmaya çalışılmıştır. 


\section{Bulgular}

Araştırmaya katılan öğrencilere “'Hak' nedir? 'Hak' denince aklına ne geliyor?” sorusu yöneltilmiş, öğrencilerin bu soruya verdikleri yanıtların dağılımı Tablo 2'de sunulmuştur.

Tablo 2. Öğrencilerin Hak Kavramına Yükledikleri Anlamların Dağılımı

\begin{tabular}{lll}
\hline Kategoriler* & $\boldsymbol{n}$ & $\mathbf{\%}$ \\
\hline Kanun/Kural & 54 & 13,08 \\
Koruma/ Güvenlik & 11 & 2,66 \\
Yapılan/İstenen & 31 & 7,51 \\
Sahip olunan/Verilen & 230 & 55,69 \\
İnanış/İlke & 18 & 4,36 \\
Ayricalık/Hak etme & 14 & 3,39 \\
Bilmiyor & 71 & 17,19 \\
Cevap Yok & 15 & 3,63 \\
\hline *Öğrenciler tarafindan birden fazla kategori belirtilmiștir.
\end{tabular}

Tablo 2'de yer alan bulgulara göre çalışmaya katılan öğrencilerin 230'u $(\% 55,69)$ hakkın sahip olunan/verilen, 31'i $(\% 7,51)$ ise yapılan/istenen bir şey olduğunu düşünürken 54'ü $(\% 13,08)$ hakk1 kanun/kural, 18'i $(\% 4,36)$ inanış/ilke, 14'ü $(\% 4,36)$ ayrıcalık/hak etme ve 11'i $(\% 2,66)$ ise koruma/güvenlik ile ilişkili bir kavram olarak açılamaktadır. Ayrıca öğrencilerden 71'i $(\% 17,19)$ hakkın ne olduğunu bilmediğini söylerken 15'i $(\% 3,63)$ ise bu soruya cevap vermemiştir. Öğrenciler sahip olunan/verilen şeyler kategorisinde tipik bir ifade olarak "Aklıma çocukların ve insanların sahip olduğu şeyler geliyor" (K321) açıklamasını yapmışlardır. Diğer kategorilerde yer alan görüş örnekleri ise aşağıdaki gibidir:

"Hak deyince aklıma yönetim geliyor." (K360, Kanun/kural kategorisi).

"Hak insanın kendini korumasıdır. Hak denince akla korumak gelir." (K73, koruma/güvenlik kategorisi).

"Hak deyince aklıma istediğini yapabilme hakkı geliyor." (K32, yapılan/istenen kategorisi).

"Bir kişinin görü̧̧ü, inandığı şeydir." (K356, inanış/ilke kategorisi).

"İnsanların hak ettiği şey." (K394, ayrıcalık/hak etme kategorisi).

Öğrencilerin sahip olduklarını düşündükleri haklarının dağılımına yönelik bulgular Tablo 3'te yer almaktadır.

Tablo 3. Öğrencilerin Sahip Olduklarını Düşündükleri Haklarının Dağılımı

\begin{tabular}{lcc}
\hline Kategoriler* & $\boldsymbol{n}$ & $\boldsymbol{\%}$ \\
\hline Kişisel (Medeni) Haklar & 147 & 35,59 \\
Ekonomik, Sosyal ve Kültürel Haklar & 291 & 70,46 \\
Korunma Hakları & 36 & 8,72 \\
Özel durumdaki çocukların korunma hakları & 0 & 0 \\
Diğer & 33 & 7,99 \\
Bilmiyor/Cevap yok & 52 & 12,59 \\
\hline
\end{tabular}

*Öğrenciler tarafından birden fazla kategori belirtilmiştir. 
Öğrencilerin 147'si (\%35,59), çocukların kişisel (medeni) haklara, 291'i (\%70,46) ekonomik, sosyal ve kültürel haklara, 36'sı (\%8,72) korunma haklarına sahip olduklarını ifade etmiştir. Ayrıca 33 $(\% 7,99)$ öğrencinin ilgili soruya verdiği yanıtlar herhangi bir kategoriye dâhil edilememiş ve diğer kategorisinde yer almıştır. Bilmiyor/cevap yok kategorisindeki $52(\% 12,59)$ öğrenciden 19'u bu soruya cevap vermemiş, kalan 33'ü ise sahip olduğu haklarının neler olduğunu bilmediğini belirtmiş ya da verdiği yanıtlara binaen sorunun konusuyla alakasız ifadeler kullandıkları görülmüştür ve bu nedenle bilmediklerine kanaat getirilmiştir.

Öğrencilerin “Çocuk olarak sahip olduğun hakların nelerdir?" sorusuna verdikleri yanıtların incelenmesiyle oluşturulan ana kategorilerin altında yer alan alt kategorilerin ayrıntılı betimlemesi Tablo 4'te sunulmaktadır.

Tablo 4. Öğrencilerin Sahip Olduklarını Düşündükleri Haklarının Alt Kategorilere Dağılımı

\begin{tabular}{|c|c|c|c|c|}
\hline Kategoriler & Alt Kategoriler* & & $n$ & $\%$ \\
\hline \multirow{7}{*}{$\begin{array}{l}\text { Kişisel } \\
\text { (Medeni) } \\
\text { Haklar }\end{array}$} & \multirow{4}{*}{ Yaşama ve Gelişme Hakkı } & Barınma Hakkı & 27 & 6,54 \\
\hline & & Beslenme Hakkı & 25 & 6,05 \\
\hline & & Giyinme Hakkı & 14 & 3,39 \\
\hline & & Yaşama Hakkı & 14 & 3,39 \\
\hline & $\begin{array}{l}\text { Katılım Hakkı (Düşünce, düşünceyi } \\
\text { açılama, vicdan ve din özgürlüğü) }\end{array}$ & & 57 & 13,80 \\
\hline & Özgür Olma Hakkı & & 44 & 10,65 \\
\hline & Ayrımcılık Yasağı (Eşitlik Hakkı) & & 6 & 1,45 \\
\hline \multirow{6}{*}{$\begin{array}{l}\text { Ekonomik, } \\
\text { Sosyal ve } \\
\text { Kültürel } \\
\text { Haklar }\end{array}$} & Eğitim Hakk1 & & 221 & 53,51 \\
\hline & Oyun Hakkı & & 143 & 34,62 \\
\hline & $\begin{array}{l}\text { Eğlenme/Boş Zamanlarını } \\
\text { Değerlendirme Hakkı }\end{array}$ & & 73 & 17,68 \\
\hline & Seyahat Hakkı & & 8 & 1,94 \\
\hline & Dinlenme Hakkı & & 5 & 1,21 \\
\hline & Sağlık Hakkı & & 5 & 1,21 \\
\hline \multirow{2}{*}{$\begin{array}{l}\text { Korunma } \\
\text { Hakları }\end{array}$} & İstismara Karşı Korunma hakk1 & & 32 & 7,75 \\
\hline & Ana-Baba Tarafından Yetiştirilme Hakkı & & 5 & 1,21 \\
\hline
\end{tabular}

*Öğrenciler tarafından birden fazla kategori belirtilmiştir.

Tablo 4'te öğrencilerin sahip olduğu hakların neler olduğuna yönelik görüşleri yer almaktadır. Toplam üç ana kategoriye ayrılan haklar kendi içlerinde de gruplara ayrılmıştır. Örneğin kişisel (medeni) haklar ana kategorisinde yaşama ve gelişme hakkı, ayrımcılık yasağı (eşitlik) hakkı, katılım hakkı (düşünce, düşünceyi açıklama, vicdan ve din özgürlüğü) ile özgür olma hakkı yer almaktadır. Ekonomik, sosyal ve kültürel haklar kendi içinde eğitim, oyun, eğlenme/boş zamanlarını değerlendirme, seyahat, dinlenme ve sağlık hakkı olarak gruplanmakta ve son olarak korunma hakları ise istismara karşı korunma ve ana-baba tarafından yetiştirilme hakkı olarak iki gruba ayrilmaktadır.

Kişisel (medeni) haklar kategorisindeki haklar incelendiğinde yaşama ve gelişme hakkının kendi içinde beslenme, barınma, giyinme ve yaşama hakkı olarak dört gruba ayrıldığı görülmektedir. Barınma hakkı 27 (\%6,54), beslenme hakkı 25 (\%6,05), giyinme hakkı $14(\% 3,39)$ ve son olarak yaşama 
hakkı da yine $14(\% 3,39)$ öğrenci tarafından sahip oldukları haklar olarak ifade edilmiştir. Yine kişisel (medeni) haklar kategorisinde bulunan katılım hakkı 57 (\%13,80), özgür olma hakkı $44(\% 10,65)$ ve ayrımcılık yasağı (eşitlik) hakkı ise $6(\% 1,45)$ öğrenci tarafından belirtilmiştir.

Ekonomik, sosyal ve kültürel haklar kategorisinde yer alan haklardan eğitim hakk1 221 $(\% 53,51)$ defa yinelenmiş ve çocukların sahip olduklarını düşündükleri haklar arasında en fazla ifade ettikleri hak olmuştur. Eğitim hakkının yanı sıra oyun hakkı 143 (\%34,62), eğlenme/ boş zaman değerlendirme hakkı $73(\% 17,68)$, seyahat hakkı $8(\% 1,94)$, sağlık hakkı $5(\% 1,21)$ ve dinlenme hakkı yine $5(\% 1,21)$ öğrenci tarafından ifade edilmiştir.

Korunma hakları kategorisindeki haklardan istismara karşı korunma hakkı $32(\% 7,75)$, anababa tarafından yetiştirilme hakkı ise $5(\% 1,21)$ defa yinelenmiştir. İstismara karşı korunma hakkı içinde en çok ifade edilen hak çalıştırılmama hakkıdır. Çalıştırılmama hakkı 22 çocuk tarafından belirtilmiş, 11 çocuk ise istismara karşı korunma hakkından bahsetmiştir. Bu çocuklardan biri her iki haktan da bahsetmiştir. Çocukların bu soruya verdikleri yanıtlardan bazıları aşağıda yer almaktadır:

"Ailede araba alınacaksa o arabanın rengini seçebilirim." (K193)

"Oyuncak, park, eğlenceli aletler ve okula gidemeyen çocuklara okuma yazma hakkı." (K351)

"Her çocuğa eşit davranılmall; kız, erkek ayrılmamall; fakir, zengin ayrılmamalı." (K202)

"Eğitim hakkl, özgürlük hakkl, oyun oynama hakkl, giyinme hakkl, eğlenme hakkı." (K206)

"Kendi kararlarm ve kararlarıma saygilı olmaları." (K8)

Tablo 5'te hakları ihlal edildiğinde öğrencilerin ne gibi yollar izleyeceklerine yönelik yanıtlarının dağılımı sunulmaktadır.

Tablo 5. Öğrencilerin Hakları İhlal Edildiğinde İzleyecekleri Yollara İlişkin Görüşlerinin Dağılımı

\begin{tabular}{lcc}
\hline Kategoriler* $^{*}$ & $\boldsymbol{n}$ & $\boldsymbol{\%}$ \\
\hline Tepkisizlik & 223 & 54,00 \\
Savunma Yolları & 173 & 41,89 \\
Diğer & 21 & 5,08 \\
\hline${ }^{*}$ Öğrenciler tarafından birden fazla kategori belirtilmiştir.
\end{tabular}

Tablodaki bulgulara göre 223 (\% 54,00) öğrenci, hakları ihlal edildiğinde tepkisiz kalacağını, 173 (\% 41,89) öğrenci ise çeşitli savunma yollarını kullanabileceğini ifade etmektedir. 21 (\% 5,08) öğrencinin cevabı ise bu kategorilerle eşleştirilemediğinden diğer kategorisine dâhil edilmiştir. Öğrencilerin soruya verdikleri yanıtlar bu ana kategoriler içerisinde daha detaylı olarak alt kategorilere ayrılmış ve Tablo 6'da sunulmuştur.

Tablo 6. Öğrencilerin Hakları İhlal Edildiğinde İzleyecekleri Yollara İlişkin Görüşlerinin Ayrıntılı Betimlenmesi

\begin{tabular}{llll}
\hline Kategoriler & Alt Kategoriler* $^{*}$ & $\boldsymbol{n}$ & $\boldsymbol{\%}$ \\
\hline \multirow{2}{*}{ Tepkisizlik } & Ne yapacağımı bilmiyorum. & 194 & 46,97 \\
& Hiçbir şey yapmam. & 29 & 7,02 \\
\hline
\end{tabular}




\begin{tabular}{lllll}
\hline & \multirow{2}{*}{$\begin{array}{l}\text { Bireysel } \\
\text { Savunma }\end{array}$} & $\begin{array}{l}\text { Şiddet/Hakaret/Bă̆ırma/Kızma/Sözlü } \\
\text { Yyarıda bulunurum. }\end{array}$ & 68 & 16,46 \\
\cline { 2 - 5 } Yolları & Mücadele & Eylem yaparım. & 15 & 3,63 \\
& \multirow{2}{*}{ Ortak } & Yetkili mercie şikâyet ederim. & 54 & 13,08 \\
& \multirow{2}{*}{ Mücadele } & Büyüklerden yardım alırım. & 23 & 5,57 \\
& & Kamuoyu oluştururum. & 18 & 4,36 \\
\hline Diğer & & 21 & 5,08 \\
\hline
\end{tabular}

*Öğrenciler tarafından birden fazla kategori belirtilmiştir.

Çalışmaya katılan öğrencilerin hakları ihlal edildiğinde yapacağı şeyler, izleyeceği yollar Tablo 6'da yer almaktadır. Tablodaki bulgular gözden geçirildiğinde tepkisizlik kategorisi altında ne yapacağını bilmeyen $194(\% 46,97)$, hiçbir şey yapmayan $29(\% 7,02)$ öğrenci olduğu görülmektedir. Hakları ihlal edildiğinde çeşitli savunma yollarını izleyen öğrencilerden bireysel mücadele yolunu seçen 68'i $(\% 16,46)$ böyle bir durumda şiddet, hakaret, bağırma, kızma ya da sözlü uyarıda bulunacağını; 15'i $(\% 3,63)$ ise eylem yapacağını ifade etmiştir. Hakları ihlal edildiğinde ortak mücadele yolların kullanarak kendini savunan öğrencilerden $54^{\prime} \ddot{u}(\% 13,08)$ yetkili mercilere şikâyet edeceğini, 23'ü $(\% 5,57)$ büyüklerden yardım alacağını ve 18'i $(\% 4,36)$ ise kamuoyu oluşturacağını belirtmiştir. Öğrenciler tarafından verilen yanıtlardan bazıları aşağıda yer almaktadır.

"Kendi haklarım elimden alındığında çok kızar ve haklarımı kısıtlamak ne demek onlara gösteririm." (K221)

"Anneme, babama ya da öğretmenime derim." (K224)

"Ben adalete başvururum." (K239)

"Herkesle paylaşır bir kamuoyu oluştururum." (K343)

"En sevdiğim haklarım elimden alınırsa hakkımı eylem yaparak savunurum." (K297)

“Üzülmem olsun derim, biter.” (K337)

Bunların yanı sıra diğer kategorisindeki $21(\% 5,08)$ öğrenci ise "yazı yazarım, yalvarırım, intihar ederim, isyan ederim vb." yanıtlar vermişlerdir.

Tablo 7, öğrencilerin hakları ile ilgili olarak okul yönetiminden beklentilerine yönelik bulguları içermektedir.

Tablo 7. Öğrencilerin Hakları Konusunda Okul Yönetiminden Beklentilerinin Ana Kategorilerdeki Dağılımı

\begin{tabular}{lcc}
\hline Kategoriler* & $\boldsymbol{n}$ & $\boldsymbol{\%}$ \\
\hline Hakların korunması ve kullanımına ilişkin beklentiler & 101 & 24,46 \\
Eğitim süreci ve ortamına ilişkin beklentiler & 99 & 23,97 \\
Demokratik tutum ve davranışlara ilişkin beklentiler & 51 & 12,35 \\
Diğer & 27 & 6,54 \\
Bilmiyor/Cevap yok & 148 & 35,84 \\
\hline
\end{tabular}

*Öğrenciler tarafindan birden fazla kategori belirtilmiştir. 
“Çocuk olarak sahip olduğun haklar konusunda okul yönetimi ne yapmalı?" sorusuna verilen yanıtları içeren Tablo 7’ye göre öğrencilerin 101'i $(\% 24,46)$ okul yönetiminden haklarının korunması ve kullanımına, 99’u (\%23,97) eğitim süreci ve ortamına, 51'i $(\% 12,35)$ ise demokratik tutum ve davranışlara ilişkin beklentilere sahiptir. 27 (\%6,54) öğrencinin cevabı bu kategorilerden herhangi birine dâhil edilememiş ve bu yanıtların diğer kategorisinde yer alması uygun görülmüştür. Bunların yanı sıra bilmiyor/cevap yok kategorisinde yer alan $148(\% 35,84)$ öğrenciden 118'i okul yönetiminin hakları konusunda neler yapabileceğini bilmediğini belirtmiş ya da verdiği yanıtlara binaen sorunun konusu dışında ifadeler kullandıkları görülmüştür ve bu nedenle bilmediklerine kanaat getirilmiştir. 30 öğrenci ise soruya cevap vermemiştir.

Öğrencilerin “Çocuk olarak sahip olduğun haklar konusunda okul yönetimi ne yapmalı?" sorusuna verdikleri yanıtların ayrıntılı betimlemesi Tablo 8' de sunulmaktadır.

Tablo 8. Öğrencilerin Hakları Konusunda Okul Yönetiminden Beklentilerinin Alt Kategorilerdeki

$$
\text { Dağılımı }
$$

\begin{tabular}{|c|c|c|c|}
\hline Kategoriler & Alt Kategoriler* & $n$ & $\%$ \\
\hline \multirow{3}{*}{$\begin{array}{l}\text { Hakların korunması } \\
\text { ve kullanımına ilişkin } \\
\text { beklentiler }\end{array}$} & Haklarımı korusun. & 42 & 10,17 \\
\hline & Beni sahip olduğum haklar konusunda bilgilendirsin. & 35 & 8,47 \\
\hline & Haklarımı kullanmama izin versin. & 27 & 6,54 \\
\hline \multirow{4}{*}{$\begin{array}{l}\text { Eğitim süreci ve } \\
\text { ortamına ilişkin } \\
\text { beklentiler }\end{array}$} & Okulun fiziki şartlarını iyileştirsin. & 37 & 8,96 \\
\hline & Okulda sosyo-kültürel etkinlikler düzenlesin. & 33 & 7,99 \\
\hline & Okulun temizliğini sağlasın. & 18 & 4,36 \\
\hline & Okulun teknolojik araç-gereç ihtiyacını gidersin. & 14 & 3,39 \\
\hline \multirow{4}{*}{$\begin{array}{l}\text { Demokratik tutum ve } \\
\text { davranışlara ilişkin } \\
\text { beklentiler }\end{array}$} & Haklarıma saygı duysun. & 21 & 5,08 \\
\hline & Tüm öğrencilere eşit/yansız davransın. & 12 & 2,91 \\
\hline & $\begin{array}{l}\text { Bir karar alınacaksa oylama yaparak çoğunluğun kararını } \\
\text { uygulasın. }\end{array}$ & 11 & 2,66 \\
\hline & Dürüst olsun ve uyulması gereken kurallara uysun. & 7 & 1,69 \\
\hline
\end{tabular}

*Öğrenciler tarafından birden fazla kategori belirtilmiştir.

Öğrencilerin, hakların korunması ve kullanımına ilişkin olarak okul yönetiminden beklentileri incelendiğinde bu kategorideki yanıtlardan 42 'sinin $(\% 10,17)$ haklarımı korusun, 35'inin $(\% 8,47)$ beni sahip olduğum haklar konusunda bilgilendirsin, 27'sinin $(\% 6,54)$ ise haklarımı kullanmama izin versin kategorisinde yer aldığı görülmektedir. Bu kategoride yer alan yanıtlardan bazıları şu şekildedir: "Bizi korumak amaçlı planlama ve eğitici koruma dersleri vermeli." (K351), "Bir konferans ya da toplantı yaparak bize haklarımızı anlatmalı." (K298).

Eğitim süreci ve ortamına ilişkin beklentilerden 37'sinin $(\% 8,96)$ okulun fiziki şartlarının iyileştirilmesine, 33'ünün $(\% 7,99)$ okulda sosyo-kültürel etkinlikler düzenlenmesine, 18'inin $(\% 4,36)$ okulun temizliğinin sağlanmasına ve 14'ünün $(\% 3,39)$ ise okulun teknolojik araç-gereç ihtiyaçlarının giderilmesine yönelik olduğu görülmektedir. Bu kategoride yer alan yanıtlardan bazıları şu şekildedir: "Tuvaletlerin daha sık yıkanması" (K361), "Bize basket potaları, futbol sahaları ve oyun bahçeleri ayrıca laboratuvar yapmall." (K318), "Çeşitli kulüpler açsın." (K388) 
Demokratik tutum ve davranışlara ilişkin beklentiler incelendiğinde ise $21(\% 5,08)$ çocuğun okul yönetiminden haklarına saygı duymasını, 12’sinin (\%2,91) tüm öğrencilere eşit/yansız davranmasını, 11'inin (\%2,66) bir karar alınacaksa oylama yaparak çoğunluğun kararını uygulamasını ve 7 'sinin $(\% 1,69)$ ise dürüst olmasını ve uyulması gereken kurallara uymasını istediği görülmüştür. Bu kategoride yer alan yanıtlardan bazıları şu şekildedir: "Herkese eşit şekilde şanslar vermelidir." (K202), “Okul yönetimi her konuda dürüst olsun, bir kurala uyulacaksa ilk başta onlar uysun." (K162), "Ne yapılacaksa bizim fikrimizi de almalı, oylama yapıp yapılacaklara karar vermeli." (K6)

Öğrencilerin okul yönetiminden beklentileri incelendiğinde alt kategorilerin aynı zamanda ÇHS'de yer alan hak sınıflaması ile de uyumlu olduğu görülmüştür. ÇHS'ye göre çocuk hakları yaşama, gelişme, korunma ve katılım hakkı olmak üzere dört kategoriye ayrılmaktadır. Bu doğrultuda öğrencilerin sahip olunan haklar konusunda bilgilendirilme, haklarına sayg1 duyulması ve eşit/yansız davranılmasına yönelik beklentileri hem gelişme hem de korunma hakkı ( $n=68)$; haklarının korunmasına ilişkin beklentileri yalnızca korunma hakkı (n=42); haklarını kullanmalarına izin verilmesi ve alınan kararlarda oylama yoluyla çoğunluğun kararının uygulanması ile ilgili beklentileri ise katılım hakkı $(n=38)$ kategorisinde değerlendirilebilir. Buradan hareketle öğrencilerin hakları konusunda okul yönetiminden beklentilerinin sırasıyla en çok korunma, ardından gelişme ve son olarak katılım hakkı kategorisinde yer aldı̆̆ı söylenebilir.

Öğrencilerin sahip oldukları hakları konusunda öğretmenlerden ne gibi beklentilerinin olduğuna yönelik yanıtlarının ana kategorilere dağılımı Tablo 9'da yer almaktadır.

Tablo 9. Öğrencilerin Sahip Oldukları Hakları Konusunda Öğretmenlerden Beklentilerinin Ana Kategorilerdeki Dağılımı

\begin{tabular}{lcc}
\hline Kategoriler* & $\boldsymbol{n}$ & $\boldsymbol{\%}$ \\
\hline Eğitim süreci ve ortamına ilişkin beklentiler & 143 & 34,62 \\
Hakların korunması ve kullanımına ilişkin beklentiler & 117 & 28,33 \\
Demokratik tutum ve davranışlara ilişkin beklentiler & 49 & 11,86 \\
Diğer & 12 & 2,91 \\
Bilmiyor/Cevap yok & 98 & 23,73 \\
\hline
\end{tabular}

*Öğrenciler tarafından birden fazla kategori belirtilmiştir.

Tablo 9’a göre öğrencilerin 143'ü $(\% 34,62)$ öğretmenlerden eğitim süreci ve ortamına, 117’si $(\% 28,33)$ hakların korunması ve kullanımına, 49'u $(\% 11,86)$ ise demokratik tutum ve davranışlara ilişkin beklentilere sahiptir. 12 (\%2,91) öğrencinin cevabı bu kategorilerden herhangi birine dâhil edilememiş ve bunların diğer kategorisinde yer alması uygun görülmüştür. Ayrıca bilmiyor/cevap yok kategorisinde yer alan 98 (\%23,73) öğrenciden 23’ü soruya cevap vermemiş, 75'i ise hakları konusunda öğretmenlerin neler yapabileceğini bilmediğini belirtmiştir.

Öğrencilerin “Çocuk olarak sahip olduğun haklar konusunda öğretmenler ne yapmalı?” sorusuna verdikleri yanıtların ayrıntılı betimlemesi Tablo 10'da sunulmaktadır. 
Tablo 10. Öğrencilerin Sahip Oldukları Hakları Konusunda Öğretmenlerden Beklentilerinin Alt Kategorilerdeki Dağılımı

\begin{tabular}{|c|c|c|c|}
\hline Kategoriler & Alt Kategoriler* & $n$ & $\%$ \\
\hline \multirow{4}{*}{$\begin{array}{l}\text { Eğitim süreci ve } \\
\text { ortamına ilişkin } \\
\text { beklentiler }\end{array}$} & Daha kaliteli eğitim versinler. & 113 & 27,36 \\
\hline & $\begin{array}{l}\text { Beden Eğitimi ve Spor } \\
\text { derslerini aksatmadan } \\
\text { yapsınlar. }\end{array}$ & 20 & 4,84 \\
\hline & $\begin{array}{l}\text { Öğrencilere şiddet } \\
\text { uygulamasın ve bağırmasınlar. }\end{array}$ & 10 & 2,42 \\
\hline & $\begin{array}{l}\text { Okulda sosyo-kültürel } \\
\text { etkinlikler düzenlesin. }\end{array}$ & 4 & 0,97 \\
\hline \multirow{3}{*}{$\begin{array}{l}\text { Hakların korunması } \\
\text { ve kullanımına ilişkin } \\
\text { beklentiler }\end{array}$} & Haklarımı korusun. & 63 & 15,25 \\
\hline & $\begin{array}{l}\text { Beni sahip olduğum haklar } \\
\text { konusunda bilgilendirsin. }\end{array}$ & 44 & 10,65 \\
\hline & $\begin{array}{l}\text { Haklarımı kullanmama izin } \\
\text { versin. }\end{array}$ & 10 & 2,42 \\
\hline \multirow{3}{*}{$\begin{array}{l}\text { Demokratik tutum ve } \\
\text { davranışlara ilişkin } \\
\text { beklentiler }\end{array}$} & $\begin{array}{l}\text { Tüm öğrencilere eşit/yansız } \\
\text { davransın. }\end{array}$ & 23 & 5,57 \\
\hline & Haklarıma saygı duysun. & 20 & 4,84 \\
\hline & $\begin{array}{l}\text { Bir karar alınacaksa oylama } \\
\text { yaparak çoğunluğun kararını } \\
\text { uygulasın. }\end{array}$ & 6 & 1,45 \\
\hline
\end{tabular}

*Öğrenciler tarafından birden fazla kategori belirtilmiştir.

Öğrencilerin hakları konusunda eğitim süreci ve ortamına ilişkin olarak öğretmenlerden beklentileri incelendiğinde bu kategorideki yantlardan 113'ünün $(\% 27,36)$ daha kaliteli eğitim verilmesine, 20 'sinin $(\% 4,84)$ beden eğitimi ve spor derslerinin aksatılmadan yapılmasına, 10'unun $(\% 2,42)$ öğrencilere şiddet uygulanmaması ve bağırılmamasına, $4^{\prime}$ ünün $(\% 0,97)$ ise okulda sosyokültürel etkinlikler düzenlenmesine yönelik beklentiler olduğu görülmektedir. Bu kategoride yer alan yanıtlardan bazıları şu şekildedir: "İyi bir eğitim vermeye çalışmalılar." (K378), "Çocuklara kızmamalılar, dövmemeliler." (K396), "Bizi Beden'e çıkarmamazlık yapmasınlar." (K319)

Hakların korunması ve kullanımına ilişkin beklentilerden 63'ünün $(\% 15,25)$ haklarımı korusun, 44'ünün $(\% 10,65)$ beni sahip olduğum haklar konusunda bilgilendirsin, $10^{\prime}$ unun $(\% 2,42)$ ise haklarımı kullanmama izin versin kategorisinde yer aldığı görülmektedir. Bu kategoride yer alan yanıtlardan bazıları şu şekildedir: "Çocuklara haklarını öğretmeliler." (K8), "Çocukların hakkını korumalı." (K14).

Demokratik tutum ve davranışlara ilişkin beklentiler incelendiğinde ise öğrencilerin 23'ünün öğretmenlerden $(\% 5,57)$ tüm öğrencilere eşit/yansız davranmasını, 20'sinin $(\% 4,84)$ haklarına sayg1 duymasını, 6'sının $(\% 1,45)$ bir karar alınacaksa oylama yaparak çoğunluğun kararını uygulamasını istediği görülmüştür. Bu kategoride yer alan yanıtlardan bazıları şu şekildedir: "Benim hakkımı bana verip hoşgörülü, eşit davranmall, adaletli olmah." (K397), "Çocukların haklarına saygılı olmalı." (K5), "Herkese aynı sevgiyi vermeli ve aynı eşitlikte davranmalıdır." (K394). 
ÇHS'de yer alan hak sınıflaması doğrultusunda incelendiğinde ise öğrencilerin kaliteli eğitim alma, beden eğitimi ve spor derslerinin aksatılmaması, okulda sosyo-kültürel etkinlikler düzenlenmesi ile ilgili beklentileri gelişim hakkı ( $n=137)$; öğrencilere şiddet uygulanmaması, bağırılmaması ve haklarının korunması noktasındaki beklentileri korunma hakkı (n=73); sahip olunan haklar konusunda bilgilendirilme, haklarına saygı duyulması ve eşit/yansız davranılmasına yönelik beklentileri hem gelişme hem de korunma hakkı ( $n=87)$; haklarını kullanmalarına izin verilmesi ve alınan kararlarda oylama yoluyla çoğunluğun kararının uygulanması ile ilgili beklentileri ise katılım hakkı (n=16) kategorisinde değerlendirilebilir. Buradan hareketle öğrencilerin hakları konusunda öğretmenlerinden beklentilerinin sırasıyla en çok gelişim, ardından korunma ve en son katılım hakkı kategorisinde yer aldığı görülmektedir.

\section{Sonuç ve Tartışma}

Çalışmadan elde edilen sonuçlara göre öğrenciler hak kavramının sözlük/literatüre dayalı tanımını yapamasalar da hak kavramı ile ilişkili olabilecek dolaylı anlatım yapabilmektedirler. Ancak bir kavramın ne anlama geldiğine, nelerle ve kimlerle ilişkili olduğuna ilişkin yüzeysel, yanlış ve eksik bilgi, kavramın getirdiği yararlar, sorumluluklar ve yükümlülüklerle ilgili beklenti ve davranışların da yüzeysel olmasına yol açar. "Hayat Bilgisi", "Sosyal Bilgiler" derslerini ve özellikle de tamamen hak kavramını öğretmeyi amaçlayan bir ders olan "İnsan Hakları, Yurttaşlık ve Demokrasi” dersini alan bu öğrencilerin hak kavramına yönelik tanımlamalarındaki eksiklik hem yaşları ile ilişkilendirilebilir hem de hakların öğretildiği derslerde kavram üzerinde yeterince bilgilendirme yapılmadı̆̆ı şeklinde açıklanabilir.

Konu hakkında fikir beyan eden öğrencilerin hakkı daha çok sahip olunan/verilen bir şey olarak gördükleri sonucuna ulaşılmıştır. Buradan hareketle öğrenciler hak kavramını, sahip oldukları ya da birileri tarafından kendilerine verilen bir kavram olarak değerlendirmektedirler. Konu ile ilgili çalışmalardan bazılarında çocuğun haklarına yönelik algılarının bulundukları ekonomik duruma (Ersoy, 2011) ya da sosyo-kültürel ortama göre şekillendiği ve bu durumların çocuğa bir bakış açısı kazandırarak algılarını etkilediği sonucuna varılmıştır (Mayall, 2000; Morss, 2002). Ruck, Keating, Abramovitch ve Koegl'in (1998) çalışmalarına katılan öğrenciler ise hakkı daha çok yapılan/istenen bir kavram olarak görmüşlerdir. Yine bahsi geçen çalışmada soruya cevap veremeyen öğrenci sayısının fazlalığı bu çalışmayla benzerlik göstermektedir.

Çocuklar sahip olduklarını düşündükleri haklar arasında en çok ekonomik, sosyal ve kültürel haklara ardından da kişisel (medeni) haklara karşılık gelen haklara yer vermişlerdir. Korunma hakları ise çok az öğrenci tarafından belirtilmiştir. Çocuğun korunma hakkının çok az öğrenci tarafından belirtilmiş olması, korunma hakkına hem geçmiş zamanlı müfredatta (Özdemir-Uluç, 2008) hem de yeni müfredatta (İnsan Hakları, Yurttaşlık ve Demokrasi dersi) yeterince yer verilmemesiyle 
ilişkilendirilebilir. Bir başka ifade ile korunma hakkının çocuklara yeterince açılanmıyor olması bu durumun sebeplerinden biri olarak görülebilir.

Ekonomik, sosyal ve kültürel haklar arasından öğrenciler en çok eğitim ve oyun hakkını ifade etmiştir. Diğer araştırmalarda da (Çarıkçı, 2019; Demirezen, Altınkulaç ve Akhan, 2013; Ersoy, 2011; Ertaş, Ertaş ve Kubilay, 2017; Gültekin, Gürdoğan-Bayır ve Balbağ, 2016; Hareket, 2018; Hareket ve Yel, 2017; Kaymak-Özmen, Öcal ve Özmen, 2014) bu bulguyu destekleyen sonuçlara ulaşılmış ve hakları sorulduğunda çocukların, eğitim ve oyun oynama hakları üzerinde yoğunlaştıkları görülmüştür. Bu sonuç çocukların hem okul içinde olmaları hem de oyunun onlar için yaşamsal bir ihtiyaç olması nedeniyle bu haklara yönelik bir farkındalığa sahip oldukları biçiminde yorumlanabilir. Ekonomik, sosyal ve kültürel haklar kategorisindeki diğer hakları (örneğin; eğlenme/boş zamanlarını değerlendirme, seyahat, dinlenme, sağlık) belirten öğrenci sayısı ise oldukça azdır. Öğrenciler kişisel (medeni) haklardan en çok yaşama ve gelişme hakkına (sırasıyla barınma, beslenme, giyinme ve yaşama) ve ardından katılım ve özgür olma haklarına değinmişlerdir. Ayrımcılık yasağı (eşitlik) hakkı ise çok az öğrenci tarafından belirtilmiştir. Bu durum çocukların fiziksel ihtiyaçları ile ilgili olarak günlük yaşamda ihtiyaç duydukları kişisel (medeni) haklarını ihtiyaç olarak hissettikleri için daha iyi bildikleri, fakat katılım, özgür olma ve eşitlik gibi daha soyut olan haklarını ise yeterince ifade edemedikleri şeklinde yorumlanabilir. Korunma hakları da bir önceki sonuçta ifade edildiği gibi çok az bahsedilen haklardandır ve bu kategoride belirtilen hakların genellikle istismara karşı korunmaya yönelik olduğu sonucuna ulaşılmıştır. Literatürde korunma haklarının öğrenciler tarafından az bilinen haklar arasında yer aldığı sonucuna ulaşılan farklı çalışmalar (Çavuş, 2019; Demirezen vd., 2013) da bulunmaktadır. Ancak Covell ve Howe (1999) ise bu araştırmalar ile uyuşmayan bir sonuca ulaşmış ve korunma hakkının öğrenciler tarafından en fazla değinilen haklar arasında yer aldığını tespit etmişlerdir. Melton ve Limber (1993) ise araştırmalarında çocukların haklarına ilişkin algılarının kültürel farklılıklara göre biçimlendiği sonucuna ulaşmışlardır. Örneğin Amerika Birleşik Devletleri'ndeki çocuklar düşüncelerini açıklama ve kendilerini ilgilendiren konularda karar alma süreçlerine katılım haklarını vurgulamaktayken Norveçli çocuklar yaşam ve gelişim ile korunma hakları üzerinde yoğunlaşmaktadırlar.

Haklarının ihlal edilmesi durumunda sergileyecekleri tavır sorulduğunda öğrencilerin çoğu tepkisiz kalacağını ifade etmiştir. Bulgulara göre bu öğrencilerin tepkisiz kalmalarının altında yatan en önemli neden, böyle bir durumda ne yapacaklarını bilememeleri ve otoriter aile ve toplum kuralları içinde (sessiz kalma, kararlara katılmama, büyüklere karşı gelmenin saygısızlık olarak görülmesi vb.) tepkisiz kalmayı içselleştirmiş olmaları ile açıklanabilir. Haklarını savunma yolunu seçen öğrencilerin ise bireysel ve ortak mücadele yollarını kullanma oranlarının birbirine yakın olduğu görülmüştür. Bireysel mücadele yollarından şiddet/hakaret/bağırma/kızma/sözlü uyarıda 
bulunma ile yasal ve ortak mücadele yollarından yetkili mercie şikâyet etme, öğrenciler tarafından en çok tercih edilen savunma yollarıdır. Tüm savunma yolları içinde ise öğrenciler tarafından en çok şiddet/hakaret/bağırma/kızma/sözlü uyarıda bulunma tercih edilmektedir. Araştırmaya katılan öğrencilerin yaşları göz önüne alındığında bunlar öngörülebilir davranışlar olarak değerlendirilebilir.

Hakları konusunda okul yönetiminden beklentileri incelendiğinde en çok dikkat çeken husus, öğrencilerin büyük bir kısmının okul yönetiminin bu konuda neler yapabileceğine yönelik bilgisinin olmamasıdır. Konu hakkında fikir beyan eden öğrenciler ise daha çok "hakların korunması ve kullanımı" ile "eğitim süreci ve ortamına" ilişkin beklentilere sahiptir. Okul yönetiminden "demokratik tutum ve davranışlara" yönelik beklentiler ise oldukça azdır ve bu durum okul yöneticilerinin kişilik yapıları ile ilgili beklentilerinin daha düşük olduğu şeklinde yorumlanabilir. Okul yönetiminden haklarının korunması ve kullanımına yönelik beklentisi olan öğrenciler, bu kategoride yöneticilerden en çok haklarını korumalarını istemekteyken sonrasında hakları konusunda bilgilendirmelerini ve haklarını kullanmalarına izin vermelerini talep etmektedirler. Öğrencilerin eğitim süreci ve ortamına ilişkin beklentileri ise okulun fiziki şartlarının iyileştirilmesi ve okulda sosyo-kültürel etkinlikler düzenlenmesi üzerinde yoğunlaşmıştır. Okulun temizliğinin (özellikle tuvalet temizliği) sağlanması ve teknolojik donanımındaki eksikliklerinin giderilmesi ise az da olsa öğrenciler tarafından ifade edilen diğer hususlardır. Okul yönetiminden demokratik tutum ve davranışlara yönelik beklentisi olan öğrenciler ise daha çok haklarına saygı duyulmasını, tüm öğrencilere eşit ve dürüst davranılmasını beklemektedirler.

Çalışmaya katılan öğrencilerin hakları konusunda öğretmenlerden beklentileri incelendiğinde ise öğrencilerin, hakları konusunda öğretmenlerin üzerine düşen görevleri, okul yönetiminin üzerine düşen görevlerden nispeten daha fazla bildikleri ortaya çıkmıştır. Öğrenciler, okul yönetiminden beklentilerinden farklı olarak öğretmenlerden daha çok eğitim süreci ve ortamına yönelik beklentilere sahiplerdir. Eğitim süreci ve ortamının ardından haklarının korunması ve kullanımına ilişkin beklentileri olan öğrenciler, demokratik tutum ve davranışlara yönelik beklentilerini yine daha az ifade etmişlerdir. Öğrencilerin eğitim süreci ve ortamına yönelik olarak öğretmenlerden beklentileri en çok daha kaliteli eğitim vermeleri yönündedir. Ayrıca beden eğitimi ve spor dersinin aksatılmadan yapılmasının ifade edilmesi bu anlamda bir eksiklik olduğu düşüncesini doğurmaktadır. Öğrencilerin bir bölümü bu derste farklı derslerin işlendiğine yönelik ifadeler kullanmışlardır. Bu durum çocukların oyun, eğlenme ve boş zamanlarını değerlendirme hakkını kullanabilmelerinin önünde bir engel teşkil etmektedir. Öğretmenlerden haklarının korunması ve kullanımına yönelik beklentisi olan öğrenciler, bu kategoride öğretmenlerden en çok haklarını korumalarını istemekteyken sonrasında hakları konusunda bilgilendirmelerini ve hakların kullanmalarına izin vermelerini talep 
etmektedirler. Öğretmenlerden demokratik tutum ve davranışlara yönelik beklentisi olan öğrenciler ise sırasıyla tüm öğrencilere eşit davranılmasını ve haklarına saygı duyulmasını istemektedirler.

Öğrencilerin hakları konusunda okul yöneticileri ve öğretmenlerden beklentileri birlikte değerlendirildiğinde hakların korunması ve kullanımı (haklar konusunda bilgilendirme, hakların korunması ve kullanımına izin verme), demokratik tutum ve davranışlar (eşit ve yansız davranma, karar alma ve karara katılma haklarının gözetilmesi ile dürüstlük) ile sosyo-kültürel etkinlik düzenlemeye yönelik beklentilerinin ortak olduğu sonucuna ulaşılmıştır. Öte yandan öğrencilerin okul yöneticileri ve öğretmenlerden eğitim süreci ve ortamına yönelik beklentileri ise farklılaşmaktadır. Bu kategori altında öğrenciler, okul yöneticilerinden okulun fiziki şartları, temizliği ve teknolojik donanımının iyileştirilmesine yönelik beklentilere sahipken öğretmenlerinden ise sınıf içi süreçlerde şiddet olmamasını, her dersi aksatmadan yapmalarını ve nitelikli eğitim vermelerini beklemektedirler. Fazlıŏlu'na (2007) göre bu beklentilerin karşılanabilmesi için öğretmenlerin ve okul yöneticilerinin çocuk haklarına yönelik farkındalıklarının yüksek olması gerekmektedir. Bu doğrultuda gerçekleştirdiği çalışmada Fazlıŏlu (2007), ilkokullarda görev yapan öğretmenler ve okul yöneticilerinin çocuk haklarının okul ortamında var olmasının önemli ve gerekli olduğunu ancak bu hakların okul ortamında varlığının istenen seviyede olmadığını düşündükleri sonucuna ulaşmıştır. Bu sonucu ise öğretmen ve yöneticilerin çocuk haklarının önemini kavramış oldukları ancak uygulamada istenilen düzeyde olunmadığı biçiminde yorumlamıştır.

Bu çalışmanın sonuçları doğrultusunda "hak" kavramının tanımı, çocukların sahip olduğu haklar ve bu hakların korunması noktasında yapılabilecek uygulamalar, ihlal edilmesi durumunda başvurulabilecek merciler, öğretmenlerin ve okul yönetiminin bu konuda üstlenebileceği rol ve sorumluluklar gibi konuların eğitim programları kapsamına dâhil edilmesi önerilebilir. Ek olarak bu çalışma Ankara ilindeki sınırlı sayıda dördüncü sınıf öğrencisi ile gerçekleştirildiğinden bir sınırlılığa sahiptir. Bu nedenle farklı il ve sınıf düzeylerinde benzer çalışmaların yapılması bu çalışmanın sonuçlarının genellenebilmesi ya da daha güvenilir sonuçlara ulaşılması açısından önemli görülmektedir.

\section{Kaynaklar}

Akyüz, E. (2000). Çocuğun haklarının ve güvenliğinin korunması. Ankara: Milli Eğitim.

Akyüz, E. (2016). Çocuk hukuku: Çocukların hakları ve korunması. Ankara: Pegem.

Ay-Zöğ, D. (2008). Öğrencilerin çocuk haklarını algılama düzeyleri ile akademik başarıları arasındaki ilişki (İstanbul ili Beyoğlu ilçesi örneği). (Yüksek lisans tezi). https://tez.yok.gov.tr sayfasından erişilmiştir.

Büyüköztürk, Ş., Kılıç-Çakmak, E., Akgün Ö. E., Karadeniz, Ş., \& Demirel, F. (2009). Bilimsel araştırma yöntemleri. Ankara: Pegem. 
Covell, K., \& Howe, R. B. (1999). The impact of children's rights education: A Canadian study. International Journal of Children's Rights, 7, 171-183.

Çarıkçı, S. (2019). Çocuk Hakları Eğitimi Programı'nın ilkokul 4. sınıf öğrencilerinin çocuk hakları tutum ve farkındalıklarına etkisi. (Doktora tezi). https://tez.yok.gov.tr sayfasından erişilmiştir.

Çavuş, S. (2019). Ortaokul öğrencilerinin çocuk hakları kavramına ilişkin bilişsel yapılarının incelenmesi. (Yüksek lisans tezi). https://tez.yok.gov.tr sayfasından erişilmiştir.

Demirezen, S., Altıkulaç, A., \& Akhan, N. E. (2013). “Children's rights” according to primary school students. The International Journal of Educational Researchers, 4(1), 39-52.

Drisco, J. W., \& Maschi, T. (2016). Content analysis. New York: Oxford University.

Ersoy, A. F. (2011). İlköğretim öğrencilerinin çocuk haklarına ilişkin algıları. İlköğretim Online, 10(1), 20-39.

Ertaş, H., Ertaş, B., \& Kubilay, S. (2017). İlkokul öğrencilerinin çocuk haklarını bilme düzeyleri. Ö. Pınarcık \& M. Özözen-Danacı (Ed.), Uluslararası Çocuk Hakları Kongresi (CRC) Tam Metin Kitabı içinde (s. 226-232). Ankara: Ĕ̆iten.

Fazlıŏlu, Z. (2007). Çocuk Hakları Sözleşmesinde yer alan "Çocuk Hakları" konusunda öğretmenlerin ve yöneticilerin bilinç düzeyleri. (Yüksek lisans tezi). https://tez.yok.gov.tr sayfasından erişilmiştir.

Guion, L. A. (2002). Triangulation: Establishing the validity of qualitative studies. University of Florida, Institute of Food and Agricultural Sciences. https://sites.duke.edu/niou/files/2014/07/W13Guion-2002-Triangulation-Establishing-the-Validity-of-Qualitative-Research.pdf sayfasindan erişilmiştir.

Gültekin, M., Gürdoğan-Bayır, Ö., \& Balbağ, N. L. (2016). Haklarımız var: Çocukların gözünden çocuk hakları. Adryaman Üniversitesi Sosyal Bilimler Enstitüsü Dergisi, 8(24), 971-1005. http://dergipark.org.tr/adyusbd/issue/37218/429586 sayfasından erişilmiştir.

Hareket, E. (2018). Eğitim hukuku bağlamında çocuk hakları eğitimi: Bir eylem araştırması. (Doktora tezi). https://tez.yok.gov.tr sayfasından erişilmiştir.

Hareket, E., \& Yel, S. (2017). Which perceptions do we have related to our rights as child? Child rights from the perspective of primary school students. Journal of Education and Learning, 6(3), 340349.

Izgar, G. (2017). İnsan Hakları, Yurttaşlık ve Demokrasi ders kitabının yapılandırmacı yaklaşım açısından analizi. İlköğretim Online, 16(2), 584-600.

İlhan, L. (2015). Veri toplama teknikleri. [PowerPoint Sunusu]. http://slideplayer.biz.tr/slide/2746088/ sayfasından erişilmiştir.

İnan, A. N. (1968). Çocuk hukuku. Ankara: Ankara Üniversitesi Eğitim Fakültesi. 
Jerome, L. (2016). Interpreting children's rights education: Three perspectives and three roles for teachers. Citizenship, Social and Economics Education, 15(2) 143-156.

Karaman-Kepenekçi, Y. (2000). İnsan hakları eğitimi. Ankara: Anı.

Karasar, N. (2017). Bilimsel araştırma yöntemi. Ankara: Nobel.

Kaymak-Özmen, S., Öcal, T., \& Özmen, A. (2014). The effect of children's rights training on primary school students' utilisation and knowledge level about children's rights. Education 3-13, 4(2), 138-153. doi:10.1080/03004279.2012.662520

Mayall, B. (2000). The sociology of childhood in relation to children's rights. The International Journal of Children's Rights, 8, 243-259.

Melton, G. B. (1980). Children's concepts of their rights. Journal of Clinical Child Psychology, 186-190.

Melton, G. B., \& Limber, S. P. (1993). What children's rights mean to children: Children's own views. M. Freman, \& P. Veerman (Ed.), The ideologies of children's rights içinde (s. 167-187). Dordrecht: Martinus Nijhoff.

Morss, J. R. (2002). The several social constructions of James, Jenks, and Prout: A contribution to the sociological theorization of childhood. The International Journal of Children's Rights, 10(1), 39-54.

Özdemir-Uluç, F. (2008). İlköğretim programlarında çocuk hakları. (Doktora tezi). htttps://tez.yok.gov.tr sayfasından erişilmiştir.

Ruck, M. D., Keating, D. P., Abramovitch, R., \& Koegl, C. J. (1998). Adolescents' and children's knowledge about rights: Some evidence for how young people view rights in their own lives. Journal of Adolescence, 21, 275-289.

Silverman, D. (2018). Nitel verileri yorumlama. (E. Dinç, Çev.). Ankara: Pegem.

Yıldırım, A., \& Şimşek, H. (2016). Sosyal bilimlerde nitel araştırma yöntemleri. Ankara: Seçkin.

\section{Extended Summary}

The purpose of the study is to examine 4th-grade public primary school students' opinions about their "rights". The research was carried out according to qualitative research methodology. The data were collected from 413 students at four public primary schools located in Etimesgut, Çankaya, Pursaklar, and Altındağ districts of Ankara, which were formed by typical case sampling. In order to obtain students' views about their rights the "Students Opinions on Children's Rights" questionnaire, which consists of open-ended unstructured questions and developed by researchers with expert opinions, was used. Before the data collecting phase, required permissions have been granted by Gazi University Ethical Commission and Ankara Provincial Directorate of National Education. After declared their volunteer participation in the study, the questionnaire was given to the students and collected after all students completed answering. 
For analyzing the obtained data, both descriptive and content analysis techniques were used. In this study, some of the categories were created based on the literature in order not to cause data loss or incorrect data arrangement. For example, while categorizing students' answers about what a "right" is, Melton's (1980) categories were used. In addition, the rights classification of Akyüz (2016, p. 64-80) was used in categorizing the rights that students think they have.

The answers given to the other questions in the study were categorized by bringing together certain codes and concepts derived from codes. The researchers made the code and categorization processes according to the basic content analysis. Basic content analysis is often quantitative and focuses on the use of descriptive statistics. Researchers use numbers or frequency of specific content or events to explain data (Drisco \& Maschi, 2016). Also, in order to simplify the understandability of the study, answers given to the questions have been tabulated as frequency and percentage, and direct quotes were included from time to time.

According to the results, although the students cannot define the concept of right based on dictionary/literature, they can make indirect expressions that may be related to the concept of "right". In some of the studies on the subject, it was concluded that children's perceptions of their rights are shaped according to the economic situation (Ersoy, 2011) or socio-cultural environment, and these situations affect their perceptions by giving the child a perspective (Mayal, 2000; Morss, 2002). Among the rights that children think they have, are mostly economic, social, and cultural rights and then the rights that correspond to personal (civil) rights. The right to protection has been specified by very few students.

Beside economic, social, and cultural rights, students mostly stated their right to education and right to play. This result has been interpreted as children's having an awareness of these rights because they are in school and play is a vital need for them. Of the civil rights, the students mostly touched on the right to life and development (housing, food, clothing, and living, sequentially), and then the rights to participation and freedom. The right to non-discrimination (equality) was stated by very few students. This situation was interpreted as that children know their personal (civil) rights they need in daily life as a need, but they cannot adequately express their more abstract rights such as participation, freedom, and equality. Protection rights are one of the least mentioned rights as it is said above, and it can be concluded that most of the rights in this category are for protection against abuse. Also, in the literature, there are studies that indicate protection rights are one of the least known rights among students (Çavuş, 2019; Demirezen, Altıkulaç \& Akhan, 2013).

When asked about their attitude in case of violation of their rights, most of the students stated that they would be unresponsive. According to the findings, the most important reason for these students to remain unresponsive can be explained by their inability to know what to do in such a 
situation and their internalization of being unresponsive within the authoritarian family and society rules (keeping silent, not participating in decisions, opposing adults as disrespectful, etc.). It was seen that the rate of using individual and common ways of struggle of the students who chose to defend their rights was close to each other. Students stated that they would use more violence, insult, yell, get angry and use verbal warnings while defending their rights individually; they will take legal action and complain to the competent authorities while fighting commonly.

When the expectations from the school administration regarding their rights are examined, the most striking point is that most of the students do not have information about what the school administration can do on this issue. On the other hand, students who express their opinions on the subject have more expectations about "protection and use of rights" and "educational process and environment". Expectations from the school administration for "democratic attitudes and behaviors" are quite low.

When the expectations of the students participating in the study from the teachers about their rights were examined, it was found that the students were relatively more aware of the duties of teachers regarding their rights than the duties of the school administration. Unlike the expectations of the school administration, students have more expectations from teachers about the educational process and environment. Students, who had expectations for the protection and use of their rights after the educational process and environment, again expressed fewer expectations for democratic attitudes and behaviors. Students' expectations from teachers regarding the educational process and environment are mostly that teachers should provide quality education.

In line with the results of this study, it may be suggested to include subjects such as the definition of the concept of "right", the rights of children and the practices that can be done at the point of protecting these rights, the authorities that can be applied in case of violation, the roles and responsibilities that teachers and school management can assume in the scope of the curriculum. In addition, this study has a limitation since it was conducted with a limited number of fourth-grade students in Ankara. For this reason, conducting similar studies at different provincial and class levels is considered important in terms of generalizing the results of this study or reaching more detailed results.

\section{Araştırmacıların Katkı Oranı Beyanı}

Bu çalışma birinci yazarın ikinci yazar danışmanlığı ve desteğiyle yürütmüş olduğu yüksek lisans tezinden üretilmiştir. 


\section{Destek ve Teşekkür Beyanı}

Bu araştırmada herhangi bir kurum, kuruluş ya da kişiden destek alınmamıştır.

\section{Çatışma Beyanı}

Araştırmacının araştırma ile ilgili diğer kişi ve kurumlarla herhangi bir kişisel ve finansal çıkar çatışması yoktur.

\section{Etik Kurul Beyanı}

Bu araştırma, Gazi Üniversitesi Etik Kurulunun 07.01.2021 tarih ve E.2248 sayılı onayı ile gerçekleştirilmiştir. 